\title{
HUBUNGAN MOTIVASI DENGAN MINAT LANJUTAN PENDIDIKAN KE JENJANG DIII FARMASI SISWA SMK KESEHATAN MUTIARA INSANI KOTA TANGERANG
}

\author{
Sri Hariyanto \\ Sekolah Tinggi Ilmu Kesehatan Widya Dharma Husada Tangerang \\ Email: koesharrykoes@yahoo.co.id
}

\begin{abstract}
ABSTRAK
Kesehatan sebagai salah satu unsur kesejahteraan umum harus duwujudkan sesuai dengan cita-cita bangsa Indonesia sebagaimana dimaksud dalam pembukaan UUD 1945. Pembangunan kesehatan diarahkan guna tercapainya kesadaran, kemauan dan kemampuan untuk hidup sehat bagi setiap penduduk agar dapat mewujudkan derajat kesehatan yang optimal. Profesi kefarmasian sebagai salah satu bagian integral dari sistem kesehatan dapat menjadi kunci utama dalam keberhasilan pelayanan kesehatan di pusat pelayanan kesehatan/Rumah Sakit. Tujuan penelitian ini untuk mengidentifikasi faktor-faktor yang berhubungan dengan minat lanjutan pendidikan ke jenjang DIII Farmasi pada Siswa SMK Kesehatan Mutiara Insani Kota Tangerang. Penelitian ini merupakan penelitian kuantitatif, menggunakan metode penelitian survei analitik dengan pendekatan cross sectional. Jumlah sampel yang didapat sebanyak 26 siswa kelas X. Hasil penelitian ini menunjukkan bahwa ada hubungan yang signifikan antara motivasi intrinsik dengan minat melanjukan pendidikan ke jenjang DIII Farmasi $(P$ value $=0,046)$, ada hubungan yang signifikan antara motivasi ekstrinsik dengan minat melanjukan pendidikan ke jenjang DIII Farmasi $(P$ value $=0,001)$, dan Tidak ada hubungan yang signifikan antara motivasi terdesak dengan minat melanjutkan pendidikan ke jenjang DIII Farmasi $(P$ value $=1,000)$.
\end{abstract}

Kata Kunci : Kefarmasian, Motivasi Intrinsik, Motivasi Ekstrinsik, Motivasi Terdesak

\begin{abstract}
Health as an element of general welfare must be realized in accordance with the ideals of the Indonesian people as referred to in the opening of the 1945 Constitution. Health development is directed towards the achievement of awareness, willingness and ability to live a healthy life for each population in order to realize optimal health status. The pharmaceutical profession as an integral part of the health system can be a key factor in the success of health services in health centers / hospitals. The purpose of this study was to identify the factors associated with further interest in continuing education in the DIII Pharmacy level at Mutiara Insani Health Vocational School Students in Tangerang City. This research is a quantitative study, using analytic survey research methods with cross sectional approach. The number of samples obtained was 26 students of class $X$. The results of this study indicate that there is a significant relationship between intrinsic motivation and interest in continuing education to the level of DIII Pharmacy (P value $=0.046)$, there is a significant relationship between extrinsic motivation and interest in continuing education to the level of education DIII Pharmacy $(P$ value $=0.001)$, and there is no significant relationship between urged motivation and interest in continuing education to the level of DIII Pharmacy $(P$ value $=1,000)$.
\end{abstract}

Keywords: Pharmacy, Intrinsic Motivation, Extrinsic Motivation, Urgent Motivation 


\section{PENDAHULUAN}

Kesehatan sebagai salah satu unsur kesejahteraan umum harus duwujudkan sesuai dengan cita-cita bangsa Indonesia sebagaimana dimaksud dalam pembukaan UUD 1945. Pembangunan kesehatan diarahkan guna tercapainya kesadaran, kemauan dan kemampuan untuk hidup sehat bagi setiap penduduk agar dapat mewujudkan derajat kesehatan yang optimal. Profesi kefarmasian sebagai salah satu bagian integral dari sistem kesehatan dapat menjadi kunci utama dalam keberhasilan pelayanan kesehatan di pusat pelayanan kesehatan/Rumah Sakit (Darmansyah, 2004). Strategi pengembangan dan pembinaan SMK Kesehatan dikembangkan melalui pengembangan kerja sama dengan industri kesehatan dan Rumah Sakit/poliklinik. Lulusan SMK Kesehatan melalui 3 tahun pendidikan ditambah dengan sertifikasi dari tiga lembaga yakni Kemendikbud, Kementerian Kesehatan, dan industri Partner. Kualifikasi akademis lulusan SMK Kesehatan terus ditingkatkan untuk dapat melanjutkan ke jenjang pendidikan tinggi.

SMK Kesehatan terdiri atas dua program studi, yakni kesehatan dan kefarmasian. Pada program studi kesehatan terdapat tiga kompetensi keahlian, perawat kesehatan, perawat gigi dan analis. Sedangkan pada program studi kefarmasian terdapat dua kompetensi keahlian, farmasi dan farmasi industri. Jumlah SMK Kesehatan di Indonesia saat ini adalah 449 sekolah dengan jumlah siswa pada tahun 2011 mencapai 89.801 orang. SMK Kesehatan terdapat di seluruh Indonesia kecuali di propinsi Kalimantan Barat, Kalimantan Tengah, dan Bangka Belitung. Dengan jumlah siswa terbanyak terdapat di propinsi Sulawesi Selatan dan Jawa Tengah.

Pendidikan kefarmasian di Indonesia mengacu kepada UndangUndang No.20 tahun 2003 tentang sistem pendidikan nasional. Dengan demikian jenis pendidikan kefarmasian di Indonesia mencakup pendidikan vokasi, akademik dan profesi. Pendidikan vokasi adalah jenis pendidikan diploma sesuai jenjangnya untuk memiliki keahlian ilmu terapan kefarmasian yang diakui oleh pemerintah Republik Indonesia. Pendidikan akademik merupakan pendidikan tinggi program sarjana dan pasca sarjana yang diarahkan terutama pada enguasaan disiplin ilmu pengetahuan tertentu. Pendidikan profesi merupakan pendidikan tinggi setelah program sarjana yang mempersiapkan peserta didik untuk memiliki pekerjaan dengan persyaratan keahlian khusus. 
Mengingat existing SMK Kesehatan, khususnya SMK Kesehatan saat ini dan jumlah lulusan yang tersebar di seluruh Indonesia, serta penyerapannya di pasar tenaga kerja. Karena Lulusan SMK Kesehatan ini dipersiapkan untuk melanjutkan ke jenjang pendidikan vokasional dan profesional. Berdasarkan masalah tersebut diatas, maka peneliti ingin mengetahui pengaruh motivasi siswa masuk SMK Kesehatan terhadap minat lanjutan pendidikan ke jenjang DIII Farmasi pada siswa SMK Kesehatan Mutiara Insani Kota Tangerang.

\section{METODE}

Desain penelitian yang digunakan adalah metode penelitian survey analitik dengan pendekatan metode survey cross sectional. Survey cross sectional adalah suatu penelitian untuk mempelajari dinamika korelasi antara faktor-faktor resiko dengan efek, dengan cara pendekatan, observasi atau pengumpulan data sekaligus pada suatu saat ( Notoatmodjo, 2010: 37). Berdasarkan cara pengumpulan data, penelitian ini termasuk ke dalam rancangan penelitian survei. Metode yang digunakan dalam mengumpulkan data survey melalui wawancara, tanya jawab dengan penyebaran kuesioner melalui surat (Nursalam, 2008: 82). Hal ini untuk mengetahui motivasi siswa SMK Kesehatan terhadap kelanjutan jenjang pendidikan ke DIII Farmasi. Populasi dalam penelitian ini adalah seluruh siswa kelas X SMK Kesehatan Mutiara Insani Kota Tangerang tahun 2013 yang berjumlah 26 orang.

Teknik sampling merupakan teknik pengambilan sampel. Pada penelitian ini penulis memilih cara pengambilan sampel menggunakan kelompok nonprobability sampling yaitu teknik yang tidak memberi peluang/kesempatan sama bagi setiap unsur atau anggota populasi untuk dipilih menjadi sampel. Teknik pengambilan sampelnya berupa total sampling. Penulis memilih sampel siswa kelas $\mathrm{X}$ dengan asumsi bahwa siswa yang baru masuk SMK Kesehatan, motivasi dan minatnya masih obyektif dan murni. Oleh karena populasinya 26 siswa pada kelas X SMK Kesehatan Mutiara Insani Kota Tangerang maka yang menjadi sampel dalam penelitian ini adalah populasi itu sendiri, yaitu sebanyak 26 siswa. 


\section{HASIL}

\section{Hasil Analisis Univariat}

a. Motivasi Intrinsik

Tabel 1. Distribusi Frekuensi Motivasi Intrinsik

\begin{tabular}{|c|c|c|}
\hline Motivasi Intrinsik & Jumlah & Persentase (\%) \\
\hline Rendah & 13 & 50,0 \\
\hline Tinggi & 13 & 50,0 \\
\hline Total & 26 & 100,0 \\
\hline
\end{tabular}

Berdasarkan tabel 1, dapat diketahui bahwa siswa memiliki motivasi intrinsik yang sama antara meotivasi rendah dan tinggi dengan persentase sebesar $50 \%$.

b. Motivasi Ekstrinsik

Tabel 2. Distribusi Frekuensi Motivasi Ekstrinsik

\begin{tabular}{|c|c|c|}
\hline Motivasi Ekstrinsik & Jumlah & Persentase (\%) \\
\hline Rendah & 12 & 46,15 \\
\hline Tinggi & 14 & 53,85 \\
\hline Total & 26 & 100,0 \\
\hline
\end{tabular}

Berdasarkan tabel 2, dapat ekstrinsik yang tinggi sebesar 14 diketahui bahwa lebih banyak responden $(53,85 \%)$. siswa yang memiliki motivasi

c. Motivasi Terdesak

Tabel 3. Distribusi Frekuensi Motivasi Terdesak

\begin{tabular}{|c|c|c|}
\hline Motivasi Terdesak & Jumlah & Persentase $(\%)$ \\
\hline Tidak & 12 & 46,15 \\
\hline Ya & 14 & 53,85 \\
\hline Total & 26 & 100,0 \\
\hline
\end{tabular}

Berdasarkan tabel 3, dapat diketahui bahwa lebih banyak siswa yang memiliki motivasi terdesak, yaitu sebesar 14 responden $(53,85 \%)$. 


\section{d. Minat Melanjukan Pendidikan Ke Jenjang DIII Farmasi}

Tabel 4. Distribusi Frekuensi Minat Melanjukan Pendidikan Ke Jenjang DIII Farmasi

\begin{tabular}{|c|c|c|}
\hline $\begin{array}{c}\text { Minat Melanjukan } \\
\text { Pendidikan Ke } \\
\text { Jenjang DIII Farmasi }\end{array}$ & Jumlah & Persentase $(\%)$ \\
\hline Tidak & 10 & 38,46 \\
\hline $\mathrm{Ya}$ & 16 & 61,54 \\
\hline Total & 26 & 100,0 \\
\hline
\end{tabular}

Berdasarkan tabel 4, dapat pendidikan ke jenjang DIII diketahui bahwa sebagian besar Farmasi, yaitu sebesar 16 memiliki minat untuk melanjutkan responden $(61,54 \%)$.

\section{Hasil Analisis Bivariat}

a. Hubungan Antara Motivasi Intrinsik dengan Minat Melanjukan Pendidikan Ke Jenjang DIII Farmasi

Tabel 5. Hubungan Antara Motivasi Intrinsik dengan Minat Melanjukan Pendidikan Ke Jenjang DIII Farmasi

\begin{tabular}{|c|c|c|c|c|c|c|c|}
\hline \multirow[t]{3}{*}{ Motivasi Intrinsik } & \multicolumn{4}{|c|}{$\begin{array}{c}\text { Minat Melanjukan } \\
\text { Pendidikan Ke Jenjang DIII } \\
\text { Farmasi }\end{array}$} & \multirow{2}{*}{\multicolumn{2}{|c|}{ Total }} & \multirow[t]{3}{*}{ P value } \\
\hline & \multicolumn{2}{|c|}{ Tidak } & \multicolumn{2}{|c|}{ Ya } & & & \\
\hline & $\mathbf{N}$ & $\%$ & $\mathbf{N}$ & $\%$ & $\mathbf{N}$ & $\%$ & \\
\hline Rendah & 8 & 61,54 & 5 & 38,46 & 13 & 100 & 0046 \\
\hline Tinggi & 2 & 15,38 & 11 & 84,62 & 13 & 100 & 0,046 \\
\hline
\end{tabular}

Pada uji Hubungan antara motivasi intrinsik dengan minat melanjukan pendidikan ke jenjang DIII Farmasi, diperoleh hasil uji chi square didapatkan hasil $P$ value $=0,046<$ nilai $\alpha=0,05$.
Maka $\mathrm{H}_{\mathrm{o}}$ ditolak dan $\mathrm{Ha}$ diterima sehingga dapat disimpulkan "ada hubungan yang signifikan antara motivasi intrinsik dengan minat melanjukan pendidikan ke jenjang DIII Farmasi”. 
b. Hubungan Antara Motivasi Ekstrinsik dengan Minat Melanjukan Pendidikan Ke Jenjang DIII Farmasi

Tabel 6. Hubungan Antara Motivasi Ekstrinsik dengan Minat Melanjukan Pendidikan Ke Jenjang DIII Farmasi

\begin{tabular}{|c|c|c|c|c|c|c|c|}
\hline \multirow{3}{*}{ Motivasi Ekstrinsik } & \multicolumn{4}{|c|}{$\begin{array}{c}\text { Minat Melanjukan } \\
\text { Pendidikan Ke Jenjang DIII } \\
\text { Farmasi } \\
\end{array}$} & \multirow{2}{*}{\multicolumn{2}{|c|}{ Total }} & \multirow[t]{3}{*}{ P value } \\
\hline & \multicolumn{2}{|c|}{ Tidak } & \multicolumn{2}{|c|}{$\mathbf{Y a}$} & & & \\
\hline & $\mathbf{N}$ & $\%$ & $\mathbf{N}$ & $\%$ & $\mathbf{N}$ & $\%$ & \\
\hline Rendah & 9 & 75,0 & 3 & 25,0 & 12 & 100 & 0001 \\
\hline Tinggi & 1 & 7,14 & 13 & 92,86 & 14 & 100 & 0,001 \\
\hline
\end{tabular}

Pada uji hubungan motivasi ekstrinsik dengan minat melanjukan pendidikan ke jenjang DIII Farmasi, diperoleh hasil uji Chi Square didapatkan hasil $P$ value $=0,001<$ nilai $\alpha=0,05$ maka $\mathrm{H}_{\mathrm{o}}$ ditolak dan Ha diterima sehingga dapat disimpulkan "ada hubungan yang signifikan antara motivasi ekstrinsik dengan minat melanjukan pendidikan ke jenjang DIII Farmasi”.

c. Hubungan Antara Motivasi Terdesak dengan Minat Melanjukan Pendidikan Ke Jenjang DIII Farmasi

Tabel 7. Hubungan Antara Motivasi Terdesak dengan Minat Melanjukan Pendidikan Ke Jenjang DIII Farmasi

\begin{tabular}{|c|c|c|c|c|c|c|c|}
\hline \multirow[t]{3}{*}{ Motivasi Terdesak } & \multicolumn{4}{|c|}{$\begin{array}{c}\text { Minat Melanjukan } \\
\text { Pendidikan Ke Jenjang DIII } \\
\text { Farmasi }\end{array}$} & \multirow{2}{*}{\multicolumn{2}{|c|}{ Total }} & \multirow[t]{3}{*}{ P value } \\
\hline & \multicolumn{2}{|c|}{$\begin{array}{l}\text { Tidak } \\
\end{array}$} & \multicolumn{2}{|c|}{ Ya } & & & \\
\hline & $\mathbf{N}$ & $\%$ & $\mathbf{N}$ & $\%$ & $\mathbf{N}$ & $\%$ & \\
\hline Tidak & 5 & 41,67 & 7 & 58,33 & 12 & 100 & \\
\hline Ya & 5 & 35,71 & 9 & 64,29 & 14 & 100 & 1,000 \\
\hline
\end{tabular}

Pada uji hubungan motivasi terdesak dengan minat melanjutkan pendidikan ke jenjang DIII Farmasi, diperoleh hasil uji chi square didapatkan hasil $P$ value $=1,000>$ nilai $\alpha=0,05$. Karena nilai signifikansi lebih kecil dari $\alpha$ yang ditetapkan sebesar 0,05 , maka $\mathrm{H}_{\mathrm{o}}$ diterima dan $\mathrm{Ha}$ ditolak sehingga dapat disimpulkan "Tidak ada hubungan yang signifikan antara motivasi terdesak dengan minat 
melanjutkan pendidikan ke jenjang DIII Farmasi”.

\section{DISKUSI}

\section{Hubungan Motivasi Intrinsik Dengan} Minat Melanjutkan Pendidikan Ke Jenjang DIII Farmasi

Hasil uji chi square didapatkan hasil $P$ value $=0,046<$ nilai $\alpha=0,05$. Maka $\mathrm{H}_{\mathrm{o}}$ ditolak dan Ha diterima sehingga dapat disimpulkan "ada hubungan yang signifikan antara motivasi intrinsik dengan minat melanjukan pendidikan ke jenjang DIII Farmasi”. Ini didukung sebagian besar oleh minat siswa untuk mengikuti pendidikan di SMK Kesehatan. Notoatmomodjo (2007) mengatakan bahwa motivasi berarti dorongan dari dalam diri manusia untuk bertindak atau berprilaku.

Hasil ini sesuai dengan teori motivasi (Suarli \& Bachtiar, 2010: 33) tentang aktualisasi diri (self actualization) yaitu kebutuhan untuk bisa memaksimumkan kemampuan, keahlian, dan potensi diri. Misalnya dalam menghadapi tantangan kerja. Menurut Martinez yang dikutip oleh Sumijatun (2010: 68) mengemukakan bahwa: "Peserta didik yang baik diasumsikan akan belajar secara maksimal dan menarik keuntungan dengan apa yang didapatkan selama proses pembelajaran". Pendidikan diharapkan dapat meningkatkan nilai pengetahuan/intelegensinya. Karena SMK hanya merupakan pendidikan yang belum profesional dan masih membutuhkan pengetahuan yang lebih sehingga dalam menjalankan fungsi-fungsi perawat dengan baik dan dapat diterapkan dalam praktik kefarmasian, sehingga motivasi siswa untuk melanjutkan ke jenjang pendidikan DIII Farmasi tinggi karena motivasinya berasal dari dalam diri sendiri sehingga minatnya juga tinggi.

Sebagaimana diketahui bahwa minat mempunyai fungsi sebagai pendorong yang kuat dalam mencapai prestasi dan minat juga dapat menambah kegembiraan pada setiap yang ditekuni oleh seseorang. Minat seseorang akan melahirkan perhatian spontan dan perhatian spontan yang memungkinkan terciptanya konsentrasi dalam waktu yang lama. Dengan demikian, minat merupakan landasan bagi konsentrasi. Ibarat sebuah bangunan, minat merupakan dasar atau pondasi bagi bangunan konsentrasi yang diciptakan. Pondasi itu akan semakin kokoh kalau minat semakin besar dengan terus-menerus dikembangkan.

\section{Hubungan motivasi ekstrinsik dengan minat melanjutkan pendidikan ke jenjang DIII Farmasi}

Hasil uji Chi Square didapatkan hasil $P$ value $=0,001<$ nilai $\alpha=0,05$ maka $\mathrm{H}_{\mathrm{o}}$ ditolak dan Ha diterima sehingga 
dapat disimpulkan "ada hubungan yang signifikan antara motivasi ekstrinsik dengan minat melanjukan pendidikan ke jenjang DIII Farmasi”. Ini didukung oleh sebagian besar minat siswa untuk mengikuti pendidikan di SMK Kesehatan. Uraian tersebut didukung oleh pendapat Hurlock (1990: 422) mengatakan bahwa "minat merupakan hasil dari pengalaman atau proses belajar". Lebih jauh lagi ia mengemukakan bahwa minat memiliki dua aspek, yaitu aspek kognitif dan aspek afektif. Aspek kognitif didasarkan atas konsep yang dikembangkan seseorang mengenai bidang yang berkaitan dengan minat. Konsep yang membangun aspek kognitif didasarkan atas pengalaman dan apa yang dipelajari dari lingkungan. Sedangkan aspek afektif adalah konsep yang membangun konsep kognitif dan dinyatakan dalam sikap terhadap kegiatan atau objek yang menimbulkan minat. Aspek ini mempunyai peranan yang besar dalam memotivasi tindakan seseorang.

Peranan dan fungsi minat pada setiap manusia memegang peranan penting dalam kehidupannya dan mempunyai dampak yang besar atas prilaku dan sikap, minat menjadi sumber motivasi yang kuat untuk belajar, anak yang berminat terhadap sesuatu kegiatan, baik itu bekerja maupun belajar, akan berusaha sekuat tenaga untuk mencapai tujuan yang diinginkan. Suatu minat dalam belajar merupakan suatu kejiwaan yang menyertai siswa dikelas dan menemani siswa dalam belajar. Semakin kuat atau dekat hubungan tersebut semakin besar minatnya. Motivasi siswa tinggi untuk melanjutkan pendidikan ke jenjang DIII Farmasi karena didukung oleh orangorang terdekat sehingga minatnya juga akan tinggi. Hal ini dapat meningkatkan semangat dan giat dalam proses pendidikan.

\section{Hubungan motivasi terdesak dengan minat melanjutkan pendidikan ke jenjang DIII Farmasi.}

Hasil uji chi square didapatkan hasil $P$ value $=1,000>$ nilai $\alpha=0,05$. Karena nilai signifikansi lebih kecil dari $\alpha$ yang ditetapkan sebesar 0,05 , maka $\mathrm{H}_{\mathrm{o}}$ diterima dan Ha ditolak sehingga dapat disimpulkan "Tidak ada hubungan yang signifikan antara motivasi terdesak dengan minat melanjutkan pendidikan ke jenjang DIII Farmasi”. Ini didukung karena hanya sebagian kecil saja motivasi terdesak siswa dalam mengikuti pendidikan di SMK Kesehatan.

Suarli \& Bahtiar (2002: 31) mengatakan bahwa terdesak adalah motivasi yang muncul dalam kondisi terjepit dan munculnya serentak serta menghentak dan cepat. Ini menunjukkan bahwa motivasi yang dikarenakan terdesak akan menimbulkan dampak 
minat yang kurang untuk melanjutkan pendidikan ke jenjang DIII Farmasi.

Hal ini juga mengingat pendidikan kefarmasian sebagai pendidikan keprofesian sesuai dengan hakikatnya sebagai pendidikan profesi, kurikulum pendidikan tinggi kefarmasian disusun berlandaskan kerangka konsep pendidikan yang kokoh. Kerangka konsep yang dimaksud berupa penguasaan ilmu pengetahuan dan teknologi kefarmasian. Seluruh rangkaian proses pendidikan pada program pendidikan tinggi kefarmasian harus ditata dan dilaksanakan sedemikian rupa sehingga memungkinkan peserta didik memahami, menguasai dan mengembangkan IPTEK kefarmasian yang diperlukan dalam melaksanakan pelayanan/asuhan kefarmasian sesuai tuntutan profesi kefarmasian (standar profesional). Sehingga untuk melanjutkan ke pendidikan jenjang DIII Farmasi harus ada kesadaran dari dalam diri individu itu sendiri.

Berdasarkan hal diatas, kewajiban guru SMK untuk memberikan penjelasan dan motivasi bahwa lulusan SMK Kesehatan bukanlah terminal namun terbuka peluang untuk menjadi perawat profesional melalui pendidikan berkelanjutan ke program DIII Farmasi. Hal ini sejalan dengan apa yang dikemukakan oleh Sumijatun (2011: 206) bahwa program pendidikan DIII Farmasi yang menghasilkan perawat generalis, sebagai perawat vokasional (Ahli Madya kefarmasian), dikembangkan dengan landasan keilmuan yang cukup dan landasan keprofesian yang kokoh. Perawat vokasional diharapkan memiliki tingkah laku, kemampuan, serta kompetensi dalam melaksanakan asuhan/praktik kefarmasian dasar secara mandiri dibawah supervisi. Di samping itu, mereka diharapkan mempunyai kemampuan mengelola praktik kefarmasian yang dilakukan sesuai kebutuhan klien, serta memiliki kemampuan menigkatkan mutu asuhan kefarmasian dengan memanfaatkan IPTEK kefarmasian yang maju secara tepat guna.

\section{SIMPULAN}

1. Pada uji hubungan antara motivasi intrinsik dengan minat melanjukan pendidikan ke jenjang DIII Farmasi, diperoleh hasil uji chi square didapatkan hasil $P$ value $=0,046<$ nilai $\alpha=0,05$. Maka $\mathrm{H}_{\mathrm{o}}$ ditolak dan $\mathrm{Ha}$ diterima sehingga dapat disimpulkan "ada hubungan yang signifikan antara motivasi intrinsik dengan minat melanjukan pendidikan ke jenjang DIII Farmasi".

2. Pada uji hubungan motivasi ekstrinsik dengan minat melanjukan pendidikan ke jenjang DIII Farmasi, diperoleh 
hasil uji Chi Square didapatkan hasil $P$ value $=0,001<$ nilai $\alpha=0,05$ maka $\mathrm{H}_{0}$ ditolak dan Ha diterima sehingga dapat disimpulkan "ada hubungan yang signifikan antara motivasi ekstrinsik dengan minat melanjukan pendidikan ke jenjang DIII Farmasi”.

3. Pada uji hubungan motivasi terdesak dengan minat melanjutkan pendidikan ke jenjang DIII Farmasi, diperoleh hasil uji chi square didapatkan hasil $P$ value $=1,000>$ nilai $\alpha=0,05$. Karena nilai signifikansi lebih kecil dari $\alpha$ yang ditetapkan sebesar 0,05 , maka $\mathrm{H}_{\mathrm{o}}$ diterima dan Ha ditolak sehingga dapat disimpulkan "Tidak ada hubungan yang signifikan antara motivasi terdesak dengan minat melanjutkan pendidikan ke jenjang DIII Farmasi”.

\section{DAFTAR PUSTAKA}

Adi Darmansyah, SPd, dkk. 2007. UndangUndang Kesehatan. Jakarta : Bakti Husada.

Arikunto, S. 2010. Manajemen Penelitian Cetakan Kesebelas. Jakarta : Rineka Cipta.

A. Wawan dan Dewi M. 2010. Teori \& Pengukuran Pengetahuan, Sikap, dan Perilaku Manusia. Yogyakarta: uha Medika.

Hidayat, A. A. 2010. Metode Penelitian Kesehatan Paradigma Kuantitatif. Surabaya : Health Books Publishing.

Muhibbin Syah. 2001. Psikologi Pendidikan dengan pendekatan Baru. Bandung: Remaja Rosdakarya.

Nursalam. 2008. Konsep dan Penerapan Metodologi Penelitian dan Ilmu
Kefarmasian Edisi 2. Jakarta : Penerbit Salemba Medika.

Nursalam. 2011. Manajemen Kefarmasian. Jakarta: Salemba Medika.

Profil SMK Kesehatan Mutiara Insani Kota Tangerang (2011-2012).

Santosa Singgih. 2007. SPSS. Jakarta: PT Elex Media Komputindo.

Soekidjo, Notoatmodjo. 2005. Metodologi Penelitian Kesehatan. Jakarta: Rineka Cipta.

Soekidjo, Notoatmodjo. 2005. Promosi Kesehatan Teori dan Aplikasi. Jakarta: Rineka Cipta.

Soekidjo, Notoatmodjo. 2010. Metodologi Penelitian Kesehatan Edisi Revisi. Jakarta: Rineka Cipta.

Soekidjo, Notoatmodjo. 2007. Kesehatan Masyarakat Ilmu dan Seni. Jakarta: Rineka Cipta.

Soekidjo, Notoatmodjo. 2007. Promosi Kesehatan dan Ilmu Perilaku. Jakarta: Rineka Cipta.

Sri, Praptianingsih. 2006. Kedudukan Hukum Perawat dalam Upaya Pelayanan Kesehatan di Rumah Sakit. Jakarta: Raja Grafindo Persada.

Suarli dan Bahtiar. 2002. Manajemen Kefarmasian dengan Pendekatan Praktis. Jakarta: Erlangga.

Sugiyono, 2006. Statistika untuk Penelitian. Bandung: Alfabeta.

Sumijatun. 2010. Konsep Dasar Menuju Kefarmasian Profesional. Jakarta: Trans Info Media.

Sutanto. 2007. Analisa Data Kesehatan. Depok : Fakultas Kesehatan Masyarakat Universitas Indonesia. 
